\title{
Weight and Body Measurements of Forest and Field Roe Deer
}

\author{
Bogusław FRUZIŃSKI, Jan KAEUZIŃSKI \& Jerzy BAKSALARY
}

Fruziński B., Kałuziński J. \& Baksalary J., 1982: Weight and body measurements of forest and field roe deer. Acta theriol., 27, 33: 479-488 [With 7 Tables]

Comparison was made of biometric parameters (body weight, body length, height at shoulder and length of hind food) in 546 roe deer, Capreolus capreolus (Linnaeus, 1758) from a forest population, and 789 roe deer from a field population, using variance analysis for cross classification by means of Bock's method. Statistically significant differences occurred only in respect of body weight and length. Body weight was found to exhibit greatest dynamics of growth between the 1st and 3rd year of life of the individuals in the case of both forest and field roe deer. Particularly great increase in body weight during this period ( $4.2 \mathrm{~kg}$ in bucks and $4.5 \mathrm{~kg}$ in does) was found in forest roe deer. In individuals from the field population this increase is smaller (2.5 kg in bucks and only $1.2 \mathrm{~kg}$ in does). Differences in body weight between forest and field roe deer are greatest in the youngest age classes, but are minimal in old individuals. Differences in body length between females and males are minimal in both populations, but field roe deer are significantly longer in the body than those living in the forest. There is a significant correlation between body weight and body length $(r=0.70 ; \alpha=0.01)$. Body weight is also correlated, but to a lesser degree, with length of the hind foot $(r=0.51)$ and height at the shoulder $(r=0.33)$. All these correlations are far greater in forest than in field roe deer, and in does than in bucks.

[Dept. of Game Management (B.F.) and Dept. of Statistical Methods (J.B.), Academy of Agriculture, Wojska Polskiego 71d, 60-625 Poznań, Poland and Polish Hunting Association, Research Station, 62-055 Czempiń, Poland (J.K.)].

\section{INTRODUCTION}

The existence of separate populations is easiest to demonstrate in species with a wide and often island-type distribution, since their isolation causes certain morpho-physiological differences to arise ( $\mathrm{Pe}-$ trusewicz, 1978). The long-lasting modifying effect of the habitat also leads to creation of separate ecological forms or ecotypes. In relation to roe deer attention has been drawn to the considerable behavioural differences between the form living in extensive open cultivated fields, and that living in the depths of forested areas (Kałuziński, 1979; Pielowski, 1970, 1977). Any possible morpho-physiological differences require, however, full documentation.

1 Praca wykonana w ramach problemu MR-II/15 koordynowanego przez Instytut Ekologii Polskiej Akademii Nauk. 
The purpose of the study was to compare body weights and certain other biometric parameters in roe deer living in forest and field habitats.

\section{MATERIAL AND METHODS}

Biometric measurements were made on individuals obtained from 1969-1979 in the territory of the Hunting Research Station at Zielonka, of the Academy of Agriculture in Poznań, and the experimental area of the Polish Hunting Association Research Station at Czempin. These areas represent completely different kinds of habitats. Zielonka is a wooded area of medium size, about 8,000 ha in extent, in which pine and mixed treestands and pine and oak woods predeminate (Fruziński et al., 1983). This is a forest biotope typical of the Wielkopolski region. The experimental areas of the Station at Czempin represent typical agrocenoses, with predominantly large-scale cultivated fields, in which agricultural operations are maintained on a high level (Kałuziński, 1982).

A considerable part of the individuals obtained by planned shooting were used for research purposes, a total of 1,335 individuals being examined biometrically (Table 1). On account of the anticipated distinct differences in the rate of deve-

Table 1

Numbers and age structure of the roe deer examined.

\begin{tabular}{|c|c|c|c|c|c|}
\hline $\begin{array}{l}\text { Age, } \\
\text { years }\end{array}$ & Sex & & $\%$ & $n^{\mathrm{r}}$ & $\%$ \\
\hline $1-2$ & $\begin{array}{c}\mathrm{M} \\
\mathrm{F}\end{array}$ & $\begin{array}{l}100 \\
111\end{array}$ & $\begin{array}{l}36.0 \\
41.4\end{array}$ & $\begin{array}{l}95 \\
61\end{array}$ & $\begin{array}{l}22.2 \\
16.9\end{array}$ \\
\hline $2-3$ & $\begin{array}{r}\mathrm{M} \\
\mathrm{F}\end{array}$ & $\begin{array}{l}15 \\
33\end{array}$ & $\begin{array}{r}5.4 \\
12.3\end{array}$ & $\begin{array}{l}70 \\
83\end{array}$ & $\begin{array}{l}16.3 \\
23.0\end{array}$ \\
\hline $3-4$ & $\stackrel{\mathrm{M}}{\mathrm{F}}$ & & $\begin{array}{l}15.9 \\
11.9\end{array}$ & & $\begin{array}{l}21.5 \\
19.9\end{array}$ \\
\hline $4-5$ & M & & $\begin{array}{l}18.0 \\
11.2\end{array}$ & $\begin{array}{l}49 \\
21\end{array}$ & $\begin{array}{r}11.5 \\
5.8\end{array}$ \\
\hline $5-6$ & $\stackrel{\mathrm{M}}{\mathrm{F}}$ & $\begin{array}{l}24 \\
36\end{array}$ & $\begin{array}{r}8.6 \\
13.5\end{array}$ & & $\begin{array}{l}9.1 \\
8.9\end{array}$ \\
\hline $6-7$ & $\frac{\mathrm{M}}{\mathrm{F}}$ & $\begin{array}{r}21 \\
7\end{array}$ & $\begin{array}{l}7.5 \\
2.6\end{array}$ & $\begin{array}{l}49 \\
49\end{array}$ & $\begin{array}{l}11.5 \\
13.6\end{array}$ \\
\hline$>7$ & $\begin{array}{r}\mathrm{M} \\
\mathrm{F}\end{array}$ & $\begin{array}{l}24 \\
19\end{array}$ & $\begin{array}{l}8.6 \\
7.1\end{array}$ & $\begin{array}{l}34 \\
43\end{array}$ & $\begin{array}{r}7.9 \\
11.9\end{array}$ \\
\hline Total & $\stackrel{\mathrm{M}}{\mathrm{F}}$ & $\begin{array}{l}278 \\
268\end{array}$ & $\begin{array}{l}100.0 \\
100.0\end{array}$ & $\begin{array}{l}428 \\
361\end{array}$ & $\begin{array}{l}100.0 \\
100.0\end{array}$ \\
\hline
\end{tabular}

lopment of fawns, depending on the period of shooting, and the impossibility of obtaining material at exactly the same time in both ranges (different degree of shooting intensity), only those individuals which had survived their first winter, and individuals older than this, were examined.

After disembowelling and cooling the carcass for 2-3 hours the following measurements were made: (1) body weight with accuracy to $0.1 \mathrm{~kg}$ : females were weighed together with the head, but males without head and antlers. Bucks' antlers, varying in respect of weights often not correlated with the individual's body (Pielowski, 1970), might have affected the results of the examination. In order to obtain comparable data a uniform method of measurements was adopted for the two 
groups of roe deer. The bucks' heads were cut off immediately behind the occipital condyle in front of the atlantal vertebra, (2) body length, measured from the naso-oral plate to the final sacral vertebra, (3) height at shoulder, measured from the end of the hoof of the forelegs along the middle of the leg to the shoulder when situated vertically in relation to the body, (4) length of the hind foot measured from the end of the hoof to the end of the heel.

Body measurements were made with accuracy to $1 \mathrm{~cm}$ using a non-stretching tape measure with scale of $1 \mathrm{~mm}$.

The material was divided into 7 age classes (Table 1). The age of individuals was defined at first by means of the histological method (Almasan, 1972; Stoddart, 1974; Hell et al., 1973; Szabik, 1974). After preparation in the laboratory of a large number of mandibles of forest and field roe deer it was found, however, that in the Wielkopolski region, which is usually characterized by mild winters - the cement layers are very irregularly deposited on the teeth, and therefore the method of defining age by means of tooth wear was adopted (Rieck, 1970; Pielowski, 1970). There is, however, a possibility of erroneous estimation with this method also, particularly in the case of defining age with accuracy to one year. On this account age was defined at 2-year intervals (Tables 1-7), half of the individuals being allocated to the lower class, and half to the higher age class. In such cases it is more reliable to use what is known as approximate classification than to accept uncertain categorical classification. Use was made in this study of some of the basic data given in earlier biometric studies on forest roe deer (Szczerbiński et al., 1972) and field roe deer (Kałuziński, 1978). These data were, however, based on somewhat scanty material, particularly in the case of field roe deer, although originating from these same areas.

Statistical analysis of the data obtained consisted of three stages. In the first stage, intervals of variation were given and calculation made of the arithmetical means, standard deviations and coefficients of variation, for each of the 4 characteristics examined. In the second stage analysis was made of coefficients of straight-line correlation between all six pairs of characteristic, calculating their evaluation and checking their significance with levels $\alpha=0.05$ and $\alpha=0.01$. In the final stage variance analysis was carried out for each of the 4 characteristics in the non-orthogonal system of three-direction cross classification, using Bock's method as a basis (Baksalary et al., 1977), in which the fact of differing numbers in the Wielkpolska region, which is usually characterized by mild winters - the this method is its two degrees, consisting in examination being made of the significance of different sources of variation in the initially accepted full model, including all main effects and all interacting effects, and reducing the model with insignificant sources. As one of the fundamental assumptions of Bock's method is the homogeneity of variance of random errors in all subclasses of the experimental system, it was decided to make variance analysis only for those characteristics for which the assumption of equality of variance had not been eliminated when verified by Bartlett's test.

\section{RESULTS}

The parameter characterizing individual quality is the body weight and this consequently requires more detailed analysis. Maximum growth dynamics is observed in roe deer between the 1st and 3rd year of life, this applying to both forest and field roe deer (Table 2). Particularly 
great increase in body weight is observed during this period in forest roe deer, which attain a far lower body weight than field roe deer during the first year of life. Differences in body weight between yearlings of the forest and field populations may be as much as $3.2 \mathrm{~kg}$ in the case of bucks and even as much as $5.4 \mathrm{~kg}$ in does (Table 3). Increase

Table 2

Comparison of the body weights of forest and field roe deer.

\begin{tabular}{|c|c|c|c|c|c|c|c|c|c|c|c|}
\hline $\begin{array}{l}\text { Age, } \\
\text { years }\end{array}$ & Sex & $\mathrm{n}$ & Min & $\operatorname{Max}$ & $\begin{array}{r}\text { Forest roe } \\
\overline{\mathrm{x}} \pm \mathrm{SD}\end{array}$ & $\mathrm{CV}$ & $\mathrm{n}$ & Min & $\underset{\operatorname{Max}}{\mathrm{Fi}}$ & $\begin{array}{l}\text { roe } \\
\bar{x} \pm S D\end{array}$ & $\mathrm{CV}$ \\
\hline \multirow[t]{2}{*}{$1-2$} & M & 100 & 6.0 & 18.0 & 10.67 & 22. & 95 & 9.3 & 22.2 & 13.9 & 16.3 \\
\hline & F & 111 & 6.0 & 16.0 & $9.92 \pm 2.31$ & 2 & 61 & 10.9 & 19.7 & 1.92 & 12.5 \\
\hline \multirow[t]{2}{*}{$2-3$} & M & 15 & 12.0 & 19.0 & $14.93 \pm 2.26$ & 15 & 70 & 12.0 & 21.2 & 2.07 & 12.6 \\
\hline & $\mathrm{F}$ & 33 & 10.5 & 20.0 & $2 \pm 2.14$ & 14.9 & 83 & 13.0 & 21.3 & $16.47 \pm 1.50$ & 9.1 \\
\hline \multirow[t]{2}{*}{$3-4$} & $\mathrm{M}$ & 44 & 11.0 & 21.0 & $15.86 \pm 1.91$ & 12.0 & 92 & 12.1 & 22.8 & $17.33 \pm 1.92$ & 11.1 \\
\hline & F & 32 & 12.6 & 19.0 & $15.81 \pm 1.88$ & 11.9 & 72 & 12.6 & 21.0 & $16.95 \pm 1.62$ & 9.6 \\
\hline \multirow[t]{2}{*}{$4-5$} & M & 50 & 12.0 & 21.0 & $16.25 \pm 1.97$ & 12.1 & 49 & 11.4 & 20.5 & $17.08 \pm 1.80$ & 10.5 \\
\hline & $F$ & 30 & 12.0 & 19.0 & $15.23 \pm 1.54$ & 10.1 & 21 & 14.7 & 21.0 & 1.51 & 9.0 \\
\hline \multirow[t]{2}{*}{$5-6$} & M & 24 & 13.5 & 19.0 & $16.13 \pm 1.60$ & 9.9 & 39 & 13.0 & 20.4 & $16.95 \pm 1.98$ & 11.7 \\
\hline & F & 36 & 10.0 & 22.0 & $16.07 \pm 2.41$ & 15 & 32 & 13.7 & 19.5 & $6 \pm 1.45$ & 8.9 \\
\hline \multirow[t]{2}{*}{$6-7$} & M & 21 & 14.0 & 21.0 & $16.43 \pm 1.73$ & 10.5 & 49 & 13.0 & 22.4 & $17.39 \pm 1.82$ & 10.4 \\
\hline & F & 7 & 12.6 & 18.0 & $15.66 \pm 2.07$ & 13.2 & 49 & 12.0 & 21.7 & $16.69 \pm 1.76$ & 10.5 \\
\hline \multirow[t]{2}{*}{$>7$} & M & 24 & 12.0 & 20.0 & $16.44 \pm 2.12$ & 12.9 & 34 & 12.3 & 20.2 & $16.93 \pm 1.92$ & 11.3 \\
\hline & F & 19 & 13.0 & 20.0 & $16.00 \pm 1.91$ & 12.0 & 43 & 10.8 & 23.5 & $15.91 \pm 2.35$ & 14.8 \\
\hline
\end{tabular}

Table 3

Comparison of increases in the body weight of forest and field roe deer.

\begin{tabular}{|c|c|c|c|c|c|c|}
\hline $\begin{array}{l}\text { Age, } \\
\text { years }\end{array}$ & Sex & $\begin{array}{l}\text { Body } \\
\text { Forest }\end{array}$ & $\begin{array}{r}\text { weight, kg } \\
\text { Field }\end{array}$ & $\begin{array}{l}\text { Increment, } \\
\text { Forest }\end{array}$ & $\begin{array}{l}\mathrm{kg} \\
\text { Field }\end{array}$ & $\begin{array}{c}\text { Difference, } \\
\mathrm{kg}\end{array}$ \\
\hline \multirow[t]{2}{*}{$1-2$} & M & 10.7 & 13.9 & & & 3.2 \\
\hline & $F$ & 9.9 & 15.3 & & & 5.4 \\
\hline \multirow[t]{2}{*}{$2-3$} & M & 14.9 & 16.4 & 4.2 & 2.5 & 1.5 \\
\hline & F & 14.4 & 16.5 & 4.5 & 1.2 & 2.1 \\
\hline \multirow[t]{2}{*}{$3-4$} & M & 15.9 & 17.3 & 1.0 & 0.9 & 1.4 \\
\hline & $F$ & 15.8 & 16.9 & 1.4 & 0.5 & 1.1 \\
\hline \multirow[t]{2}{*}{$4-5$} & M & 16.3 & 17.1 & 0.4 & -0.2 & 0.8 \\
\hline & F & 15.2 & 16.8 & -0.6 & -0.1 & 1.6 \\
\hline \multirow[t]{2}{*}{$5-6$} & M & 16.1 & 16.9 & -0.2 & -0.2 & 0.8 \\
\hline & $\mathrm{F}$ & 16.1 & 16.4 & 0.9 & -0.4 & 0.3 \\
\hline \multirow[t]{2}{*}{$6-7$} & M & 16.4 & 17.4 & 0.3 & 0.5 & 1.0 \\
\hline & F & 15.7 & 16.7 & -0.4 & 0.3 & 1.0 \\
\hline \multirow{2}{*}{$>7$} & M & 16.4 & 16.9 & 0.0 & -0.5 & 0.5 \\
\hline & F & 16.0 & 15.9 & 0.3 & -0.8 & -0.1 \\
\hline
\end{tabular}

in weight between the 1st and 3rd year of life in forest roe deer is about $4.2 \mathrm{~kg}$ for bucks and as much as $4.5 \mathrm{~kg}$ for does. This takes place for less dynamically in roe deer of the field population, in which this increase is correspondingly 2.5 for bucks and only 1.2 for females (Table 3). Individuals of the field population however reach far greater weight 
during the 1st year of life, and maximum weight at the age of about 3-4 years, later exhibiting only minimal increases, or even slight decreases, in weight (Table 3 ). Forest roe deer do not reach maximum weight until after the 4th year of life without, however, the periodical decreases in body weight characteristic of field roe deer (Table 3).

Differences in dynamics of increase in body weight for the two sexes are only slight in both populations, with the exception of a slight decrease in body weight of forest does from 4-5 years old (Table 3 ). The body weight of forest and field roe deer, however, differs significantly from the statistical aspect (coefficient of correlation 1.47, with level of significance of $\alpha=0.05$ ). These differences are greatest in the youngest age classes, in favour of field roe deer, but are only minimal in the oldest individuals (Table 3 ).

Statistically significant differences (coefficient of correlation 4.6, with level of significance of $\alpha=0.05$ ) between forest and field roe deer are

Table 4

Comparison of body lengths of forest and field roe deer.

\begin{tabular}{|c|c|c|c|c|c|c|c|c|c|c|}
\hline \multirow{2}{*}{ Age } & \multirow{2}{*}{ Sex } & \multicolumn{5}{|c|}{ Forest roe } & \multicolumn{4}{|c|}{ Field roe } \\
\hline & & $\mathrm{n}$ & Min & $\operatorname{Max}$ & $\overline{\mathrm{x}} \pm \mathrm{SD}$ & $\mathrm{CV}$ & Min & $\operatorname{Max}$ & $\overline{\mathrm{x}} \pm \mathrm{SD}$ & $\mathrm{CV}$ \\
\hline \multirow[t]{2}{*}{$1-2$} & M & 100 & 77.0 & 125.0 & $97.45 \pm 9.03$ & 9.3 & 91.0 & 123.0 & $108.32 \pm 5.52$ & 5.1 \\
\hline & $\mathrm{F}$ & 111 & 73.0 & 116.0 & $96.06 \pm 8.25$ & 8.6 & 97.0 & 120.0 & $108.97 \pm 5.18$ & 4.8 \\
\hline \multirow[t]{2}{*}{$2-3$} & $\mathrm{M}$ & 15 & 93.0 & 121.0 & $109.13 \pm 8.32$ & 7.6 & 104.0 & 123.0 & $113.43 \pm 4.49$ & 4.0 \\
\hline & F & 33 & 75.0 & 121.0 & $108.17 \pm 8.74$ & 8.1 & 101.0 & 121.0 & $112.20 \pm 3.95$ & 3.5 \\
\hline \multirow[t]{2}{*}{$3-4$} & M & 44 & 86.0 & 121.0 & $108.82 \pm 7.20$ & 6.6 & 105.0 & 128.5 & $114.51 \pm 4.95$ & 4.3 \\
\hline & F & 32 & 90.0 & 118.0 & $107.34 \pm 7.63$ & 7.1 & 103.0 & 122.0 & $112.58 \pm 4.10$ & 3.6 \\
\hline \multirow[t]{2}{*}{$4-5$} & M & 50 & 92.0 & 131.0 & $111.92 \pm 7.43$ & 6.6 & 104.0 & 127.0 & $114.59 \pm 4.63$ & 4.0 \\
\hline & F & 30 & 98.0 & 120.5 & $107.12 \pm 5.82$ & 5.4 & 104.0 & 118.0 & $111.00 \pm 4.55$ & 4.1 \\
\hline \multirow[t]{2}{*}{$5-6$} & $\mathrm{M}$ & 24 & 90.0 & 124.0 & $109.33 \pm 8.52$ & 7.8 & 98.0 & 123.0 & $111.68 \pm 5.67$ & 5.1 \\
\hline & F & 36 & 95.0 & 125.0 & $110.11 \pm 6.90$ & 6.3 & 100.0 & 120.0 & $112.64 \pm 4.16$ & 3.7 \\
\hline \multirow[t]{2}{*}{$6-7$} & $\mathrm{M}$ & 21 & 101.0 & 126.0 & $111.14 \pm 5.99$ & 5.4 & 109.0 & 124.0 & $115.20 \pm 3.92$ & 3.4 \\
\hline & $\mathrm{F}$ & 7 & 95.0 & 128.0 & $108.43 \pm 11.33$ & 10.4 & 103.0 & 123.0 & $113.98 \pm 4.46$ & 3.9 \\
\hline \multirow[t]{2}{*}{$>7$} & M & 24 & 102.0 & 129.0 & $111.08 \pm 5.90$ & 5.3 & 105.0 & 125.0 & $114.29 \pm 5.32$ & 4.7 \\
\hline & $\mathrm{F}$ & 19 & 103.0 & 129.0 & $114.16 \pm 6.50$ & 5.7 & 102.0 & 122.0 & $112.26 \pm 3.63$ & 3.2 \\
\hline
\end{tabular}

also observed in respect of body length (Table 4). This is undoubtedly the result of very close correlation between body weight and length, which is observed in both forest and field roe deer (Table 7). In this case also the greatest differences in favour of field roe deer are observed in animal in the youngest age classes. Differences in body length between females and males are, however, minimal in the two populations (Table 4).

The other biometric characteristic examined, i.e. height at shoulder (Table 5) and length of hind foot (Table 6) did not exhibit significant differences. Dimorphic differences in height at shoulder and length of the hind foot are only minimal and not significant. There is close cor- 
relation $(r=0.70)$ between weight and body length in roe deer, which is clearly greater in forest roe deer $(0.71)$ than in field roe deer $(0.43)$ (Table 7). Body weight is clearly correlated, although to a lesser degree, with length of the hind foot $(0.51)$ and height at shoulder $(0.33)$. The correlation between body length and length of the hind foot is also

Table 5

Comparison of height at the shoulder of forest and field roe deer.

\begin{tabular}{|c|c|c|c|c|c|c|c|c|c|c|}
\hline \multirow{2}{*}{ Age } & \multirow{2}{*}{ Sex } & \multirow[b]{2}{*}{$\mathrm{n}$} & \multicolumn{3}{|c|}{ Forest roe } & \multirow[b]{2}{*}{$\mathrm{CV}$} & \multirow[b]{2}{*}{ Min } & \multicolumn{2}{|c|}{ Field roe } & \multirow[b]{2}{*}{$\mathrm{CV}$} \\
\hline & & & Min & $\operatorname{Max}$ & $\overline{\mathrm{x}} \pm S D$ & & & Max & :SD & \\
\hline \multirow[t]{2}{*}{$1-2$} & M & 100 & 56.0 & 83.0 & $67.75 \pm 5.31$ & 7.8 & 60.0 & 78.5 & $69.95 \pm 3.45$ & 4.9 \\
\hline & F & 111 & 51.0 & 85.0 & $66.52 \pm 6.17$ & 9.3 & 63.0 & 79.0 & $71.02 \pm 3.02$ & 4.2 \\
\hline \multirow[t]{2}{*}{$2-3$} & $\mathrm{M}$ & 15 & 56.0 & 75.0 & $69.20 \pm 5.88$ & 8.5 & 64.0 & 81.0 & $71.65 \pm 3.34$ & 4.7 \\
\hline & F & 33 & 58.0 & 84.0 & $71.88 \pm 5.94$ & 8.3 & 66.0 & 82.0 & $72.33 \pm 2.95$ & 4.1 \\
\hline \multirow[t]{2}{*}{$3-4$} & M & 44 & 63.0 & 87.0 & $73.16 \pm 4.68$ & 6.4 & 65.0 & 80.0 & $72.67 \pm 2.74$ & 3.8 \\
\hline & $F$ & 32 & 59.0 & 81.0 & $73.25 \pm 5.29$ & 7.2 & 65.0 & 80.0 & $72.46 \pm 3.47$ & 4.8 \\
\hline \multirow[t]{2}{*}{$4-5$} & M & 50 & 57.0 & 96.0 & $72.54 \pm 6.00$ & 8.3 & 65.0 & 77.0 & $72.45 \pm 2.67$ & 3.7 \\
\hline & $\mathbf{F}$ & 30 & 63.0 & 89.0 & $72.72 \pm 4.68$ & 6.4 & 66.0 & 78.0 & $72.31 \pm 3.28$ & 4.5 \\
\hline \multirow[t]{2}{*}{$5-6$} & M & 24 & 61.0 & 88.0 & $72.81 \pm 5.79$ & 7.9 & 66.0 & 79.0 & $72.04 \pm 3.14$ & 4.4 \\
\hline & F & 36 & 66.0 & 86.0 & $74.08 \pm 5.06$ & 6.8 & 67.0 & 79.0 & $72.53 \pm 3.09$ & 4.3 \\
\hline \multirow[t]{2}{*}{$6-7$} & M & 21 & 66.0 & 79.0 & $73.67 \pm 3.54$ & 4.8 & 67.0 & 77.0 & $72.13 \pm 2.66$ & 3.7 \\
\hline & $\mathrm{F}$ & 7 & 58.0 & 80.0 & $70.43 \pm 7.21$ & 10.2 & 62.0 & 86.0 & $72.77 \pm 3.53$ & 4.4 \\
\hline \multirow[t]{2}{*}{$>7$} & M & 24 & 64.0 & 82.0 & $73.92 \pm 4.07$ & 5.7 & 67.0 & 78.0 & $72.50 \pm 2.73$ & 3.8 \\
\hline & $\mathrm{F}$ & 19 & 65.0 & 83.0 & $74.63 \pm 5.21$ & 7.0 & 65.5 & 79.0 & $72.84 \pm 2.88$ & 4.0 \\
\hline
\end{tabular}

Table 6

Comparison of lengths of the hind foot of forest and field roe deer.

\begin{tabular}{|c|c|c|c|c|c|c|c|c|c|c|}
\hline \multirow{2}{*}{ Age } & \multirow{2}{*}{ Sex } & \multirow[b]{2}{*}{$\mathrm{n}$} & \multirow[b]{2}{*}{ Min } & \multicolumn{2}{|c|}{ Forest roe } & \multirow[b]{2}{*}{$\mathrm{CV}$} & \multicolumn{4}{|c|}{ Field roe } \\
\hline & & & & $\operatorname{Max}$ & $\overline{\mathrm{x}} \pm \mathrm{SD}$ & & Min & Max & $\overline{\mathrm{x}} \pm \mathrm{SD}$ & CV \\
\hline \multirow[t]{2}{*}{$1-2$} & M & 100 & 28.0 & 45.0 & $33.38 \pm 2.65$ & 7.9 & 31.0 & 37.0 & $34.47 \pm 1.30$ & 3.8 \\
\hline & $\mathrm{F}$ & 111 & 25.0 & 44.0 & $32.25 \pm 2.28$ & 7.1 & 32.0 & 38.0 & $34.43 \pm 1.27$ & 3.7 \\
\hline \multirow[t]{2}{*}{$2-3$} & $\mathbf{M}$ & 15 & 33.0 & 38.0 & $34.93 \pm 1.71$ & 4.9 & 32.0 & 39.0 & $35.25 \pm 1.30$ & 3.7 \\
\hline & $\mathrm{F}$ & 33 & 24.0 & 42.0 & $35.03 \pm 2.77$ & 7.9 & 32.0 & 39.0 & $34.92 \pm 1.24$ & 3.6 \\
\hline \multirow[t]{2}{*}{$3-4$} & $\mathrm{M}$ & 44 & 31.0 & 37.0 & $35.00 \pm 1.31$ & 3.7 & 33.0 & 38.0 & $35.42 \pm 1.12$ & 3.7 \\
\hline & F & 32 & 31.0 & 38.0 & $35.16 \pm 1.46$ & 4.2 & 31.0 & 38.0 & $34.86 \pm 1.24$ & 3.6 \\
\hline \multirow[t]{2}{*}{$4-5$} & M & 50 & 29.0 & 42.0 & $35.06 \pm 2.05$ & 5.9 & 32.0 & 37.0 & $35.31 \pm 1.19$ & 3.4 \\
\hline & F & 30 & 32.0 & 38.0 & $34.93 \pm 1.60$ & 4.6 & 31.0 & 37.0 & $34.55 \pm 1.37$ & 3.9 \\
\hline \multirow[t]{2}{*}{$5-6$} & M & 24 & 33.0 & 48.0 & $36.02 \pm 2.85$ & 7.9 & 32.0 & 38.0 & $34.95 \pm 1.51$ & 4.3 \\
\hline & F & 36 & 27.0 & 43.0 & $35.19 \pm 2.28$ & 6.5 & 33.0 & 37.0 & $34.91 \pm 1.11$ & 3.2 \\
\hline \multirow[t]{2}{*}{$6-7$} & $\mathrm{M}$ & 21 & 33.0 & 47.0 & $35.76 \pm 2.77$ & 7.8 & 31.0 & 39.0 & $35.41 \pm 1.35$ & 3.8 \\
\hline & $\mathrm{F}$ & 7 & 33.0 & 37.0 & $35.14 \pm 1.58$ & 4.5 & 32.0 & 45.0 & $35.33 \pm 1.86$ & 5.3 \\
\hline \multirow[t]{2}{*}{$>7$} & $\mathrm{M}$ & 24 & 32.0 & 41.0 & $35.48 \pm 1.75$ & 4.9 & 33.0 & 37.0 & $35.16 \pm 0.94$ & 2.7 \\
\hline & $\mathrm{F}$ & 19 & 32.0 & 49.0 & $35.68 \pm 3.50$ & 9.8 & 32.0 & 39.0 & $34.67 \pm 1.24$ & 3.6 \\
\hline
\end{tabular}

significant (0.52). Correlations between body length and height at shoulder (0.31) and height at shoulder and length of the hind foot $(0.22)$, are less distinct (Table 7) but significant.

In all cases these correlations are far greater in forest than in field roe deer, and in does than in bucks (Table 7). 


\begin{tabular}{|c|c|c|c|c|c|c|c|}
\hline & I & 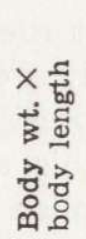 & 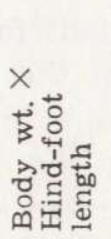 & 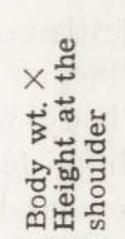 & 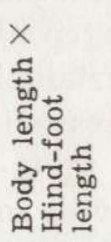 & 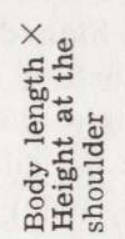 & 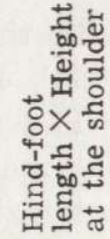 \\
\hline Total & 1335 & $0.70^{2}$ & $0.51^{2}$ & $0.33^{2}$ & $0.52^{2}$ & $0.31^{2}$ & $0.22^{2}$ \\
\hline Forest roe & 546 & $0.71^{2}$ & $0.54^{2}$ & $0.38^{2}$ & $0.53^{2}$ & $0.35^{2}$ & $0.25^{2}$ \\
\hline Field roe & 789 & $0.45^{2}$ & $0.38^{2}$ & $0.12^{2}$ & $0.43^{2}$ & $0.10^{2}$ & $0.09^{1}$ \\
\hline Bucks & 706 & $0.66^{2}$ & $0.45^{2}$ & $0.26^{2}$ & $0.49^{2}$ & $0.25^{2}$ & $0.20^{2}$ \\
\hline Does & 629 & $0.73^{2}$ & $0.56^{2}$ & $0.39^{2}$ & $0.54^{2}$ & $0.37^{2}$ & $0.25^{2}$ \\
\hline \multicolumn{8}{|l|}{ Age classes } \\
\hline $1-2$ & 367 & $0.67^{2}$ & $0.50^{2}$ & $0.18^{2}$ & $0.59^{2}$ & $0.17^{2}$ & 0.07 \\
\hline $2-3$ & 201 & $0.47^{2}$ & $0.33^{2}$ & 0.13 & $0.41^{2}$ & $0.26^{2}$ & 0.01 \\
\hline $3-4$ & 240 & $0.45^{2}$ & $0.24^{2}$ & 0.00 & $0.34^{2}$ & 0.02 & 0.10 \\
\hline $4-5$ & 150 & $0.35^{2}$ & $0.24^{2}$ & -0.09 & 0.11 & -0.02 & -0.03 \\
\hline $5-6$ & 131 & $0.42^{2}$ & $0.29^{2}$ & 0.15 & $0.21^{1}$ & 0.11 & $0.27^{2}$ \\
\hline $6-7$ & 126 & $0.45^{2}$ & $0.37^{2}$ & 0.06 & $0.28^{2}$ & 0.15 & 0.10 \\
\hline$>7$ & 120 & $0.36^{2}$ & $0.26^{2}$ & 0.03 & 0.10 & 0.15 & $0.22^{1}$ \\
\hline
\end{tabular}

1 The correlations coefficients are different from $0, \alpha=0.05$,

2 The correlations coefficients are different significantly from $0, \alpha=0.01$.

\section{DISCUSSION}

The considerable differences in body weight between forest and field roe deer are due chiefly to differences in rate of increase in body in the youngest individuals. The attainment by field roe deer fawns of far greater body weight is probably to be attributed to the abundance of food rich in all nutritive components. Vegetation of agricultural origin, which forms about $66 \%$ of the food of field roe deer over the yearly cycle (Kałuziński, 1982), in addition to the high nutritive value is also distinguished by a very high digestion coefficient, which must create far more favourable feeding conditions. In the Zielonka wooded area, in which there are numerous populations of both red and fallow deer, and considerable traffic through the wood by humans, the abundance of the food supply is certainly lesser. The situation is similar in other stretches of wooded land at no great distance (Wolsztyn district), where roe deer from 1-2 years old reach lower body weight (average $10.4 \mathrm{~kg}$ ), but the differences between forest and field roe deer there are far smaller (Wilk, 1982). Increase in body weight of forest roe deer is, however, more balanced in older age classes and distinguished by lower variations. In individuals which have completed growth, i.e. 4 years and over, differences in body weight are only slight. In different age classes of forest roe deer, however, there is a far greater coefficient of 
variability in body weight $(9.9-23.3)$ than in field roe deer $(8.9-16.3)$. This may be due primarily to the more diversified food conditons in the forest habitat, even over a relatively small area, which combined with the high degree of settlement of forest roe deer (Fruziński et al., 1982), exerts a certain influence on the body weight of individuals.

The slight decrease in body weight of forest does from 4-5 years old may be due to the high fertility of this age class (Fruziński \& Łabudzki, 1982), with somewhat limited supplies of fully nutritive food.

A limited number of other source data also point to the important influence of the field habitat on the body weight of roe deer living there, for instance, according to Ueckermann (1957) the most important factors are the quality of the soil (mother-rock), length of the boundary between forest and field, the percentage of the range formed by meadows and, to a lesser degree, the species composition of the forest. Sägesser (1966) also found a significant relation between body weight of roe deer and the length of the field-forest boundary in relation to the wooded area, expressed in the form of the appropriate coefficient. Stubbe $(1966,1979)$ given a detailed description of the body weight of different age classes of roe deer, but this applies solely to forest roe deer.

Apart from body weight it is only body length which exhibits statisticaly significant differences between individuals of the two populations, certainly caused by their differing ways of life and conditioned by habitat differences. Body length, although closely correlated with body weight (Table 7), is a characteristic exhibiting a far smaller range of individual variation in different age classes, this applying to both populations. In this case also the coefficient of variability $(5.3-10.4)$ is higher in forest roe deer than in field roe deer $(3.2-5.1)$ (Table 4).

The closest correlations occur in forest roe deer in respect of all the characteristics examined It may be concluded that although food from a forest habitat brings about a slower growth rate in individuals, it is accompanied by harmonious development of all biometric characteristics correlated with each other (Table 7). This is evidence that it is a case of a stabilized population with established morphological characteristics, living in a habitat stable from the biotopic aspect.

The far lesser degree of correlation of the various biometric characteristics in field roe deer (Table 7), with simultaneous absence of significant differences in height at shoulder and body length in the forest roe deer (Table 4 and 5), proves that it is at present difficult to foresee in which direction development of characteristics in field populations will proceed. The considerable seasonal variations in food resources and shelter of a field habitat are of importance to the deve- 
lopment of certain biometric characteristics. The modifying effect of habitat and behaviour has not as yet brought about the formation of a separate morphological type of field roe deer.

The far clearer correlation of biometric characteristics in males than in females (Table 7) cannot be interpreted with any degree of certainty. The fact of the annual formation of antlers is significant here, since it involves additional expenditure of energy during the winter period by the organism (Pielowski, 1970).

\section{REFERENCES}

1. Almasan H., 1972: Untersuchungen der Zahnstruktur zur Alterbestimmung beim Rehwild (Capreolus capreolus L.) Z. Jagdwiss., 18: 222-224.

2. Baksalary J., Kala R. \& Katulska K., 1977: Analiza wariancji dla klasyfikacji krzyżowych metodą Bocka. Roczn. Akad. roln. Poznań, 115: 3-32.

3. Essen L., 1966: Das Rehwild in Schweden. Beitr. Jagd- u. Wildforsch. 5: 143-148.

4. Fruziński B., Łabudzki L. \& Wlazełko M., 1983: Habitat, density and spatial structure of roe deer population in forest. Acta theriol., 28.

5. Fruziński B. \& Eabudzki L., 1982: Demographic processes in the forest roe deer population. Acta theriol., 27: $365-375$.

6. Hell P., Herz J. \& Ginter F., 1973: Die Bestimmung des Alters des Rehwildes nach den Ringen in Zahnzement. Folia Venat., 3: 55-70.

7. Kałuziński J., 1978: Badania biometryczne i obserwacje biologiczne sarny (Capreolus capreolus L.) populacji polnej. Roczn. Akad. roln. Poznań, 100: $73-81$.

8. Kałuziński J., 1982: Composition of the food of roe deer living in fields and the effects of their feeding on plant production. Acta theriol., 27: 457-470.

9. Klein D. R. \& Strandgaard H., 1972: Factor effecting growth and body size of roe deer. Wildl. Manage., 36: 64-79.

10. Petrusewicz K., 1978: Osobnik, populacja, gatunek. Państw. Wyd. Nauk.: 1-384. Warszawa.

11. Pielowski Z., 1970: Sarna. Państw. Wyd. Roln. i Leśne: 1-219. Warszawa.

12. Pielowski Z., 1977: Das Feldreh - Wild der Zukunft in der Agrarlandschaft. Beitr. Jagd- u. Wildforsch., 10: 193-200.

13. Rieck W., 1970: Alter und Gebissabnutzung beim Rehwild. Z. Jagdwiss., 16: $1-6$.

14. Sablina J. B., 1970: Evolucija piščevaritielnoj sistemy oleniej. Izd. Nauka: 1-248. Moskva.

15. Sägesser H., 1966: Uber den Einfluss des Standortes auf das Gewicht des Rehwildes (Capreolus c. capreolus). Z. Jagdwiss., 12: 54-62.

16. Stoddart D. M., 1974: Age determinations of roe deer (Capreolus capreolus) from annual growth layers in the dental cementum. J. Zool., London, 174: $511-537$.

17. Stubbe Ch., 1966: Körperwachstum und Körpergrösse des europäischem Rehwildes (Capreolus c. capreolus). Zool. Garten, 33: 85-105.

18. Stubbe Ch. \& Passarge H., 1979: Rehwild. VEB Deutscher Landwirtschaftsverlag: 1-432. Berlin. 
19. Szabik E., 1973: Age estimation of roe deer from different hunting-grounds of southeastern Poland. Acta theriol., 12: 223-236.

20. Szczerbiński W., Fruziński B., Grudziński R. \& Łabudzki L., 1972: Biometryczna charakterystyka populacji sarny europejskiej (Capreolus capreolus L.) na terenach Ośrodka Hodowli Zwierzyny Zielonka. Roczn. Wyższ. Szk. roln. Poznań, 57: $145-156$.

21. Ueckermann E., 1957: Wildstandsbewirtschaftung und Wildschadenverhütung beim Rehwild. Neuwied: 1-155. Hamburg u. Berlin.

22. Wilk W., 1982: Charakterystyka populacji sarny okolic Wolsztyna. Ph. D. thesis.

Accepted, July 29, 1982.

Bogusław FRUZIŃSKI, Jan KAEUZIŃSKI i Jerzy BAKSALARY

CIĘZAR I WYMIARY CIAEA LESNYCH I POLNYCH SARN

\section{Streszczenie}

$\mathrm{Na}$ podstawie porównania niektórych parametrów biometrycznych 1335 sarn, w tym 546 osobników populacji leśnej (Zielonka) i 789 sarn polnych (Czempiń) analizowano szczegółowo różnice występujące między obu populacjami (Tabela 1). Różnice istotne pod względem statystycznym (stosowano analizę wariancji dla klasyfikacji krzyżowych metodą Bocka) wystąpiły jedynie pod względem ciężaru tuszy i długości tułowia. Ciężar tuszy odznacza się największą dynamiką wzrostu między 1 a 3 rokiem życia osobnika, i to w obu badanych populacjach. Szczególrie wysoki przyrost ciężaru tuszy w tym okresie obserwujemy u sarn leśnych (4,2 kg u kozłów i 4,5 u kóz). Dla sarn populacji polnej odpowiednio: $2,5 \mathrm{~kg}$ i tylko 1,2 u kóz (Tabele 2, 3,4). Różnice ciężaru tuszy między sarną leśną i polną są najwyższe w najmłodszych klasach wieku (3,2 kg u kozłów i aż 5,4 u kóz). U osobników starszych, o ukończonym już wzroście różnice te są już jednak niewielkie (Tabele 2, 3, 4).

Istotne pod względem statystycznym różnice wystąpiły również w zakresie długości tułowia (Tabela 4). Długość tułowia jest wyraźnie skorelowana $\mathrm{z}$ ciężarem tuszy (Tabela 7) i różnice te są również największe u osobników najmłodszych, na korzyść sarn polnych. Minimalne są natomiast $w$ obu populacjach różnice długości tułowia między osobnikami żeńskimi i męskimi (Tabela 4).

Poszczególne cechy biometryczne są w znacznie wyższym stopniu skorelowane u sarn leśnych (Tabela 7) oraz u osobników żeńskich, i to $\mathrm{w}$ obu badanych populacjach. 